\title{
PERBANDINGAN DOMINASI BENTUK EMOSI LELAKI DALAM NOVEL PENYEBERANG SEMPADAN DENGAN KAFKA ON THE SHORE
}

\section{(COMPARISON OF THE MEN DOMINANT EMOTION IN THE NOVEL PENYEBERANG SEMPADAN AND KAFKA ON THE SHORE)}

\author{
Maznida Mahadi \\ Tengku Intan Marlina Tengku Mohd Ali \\ Akademi Pengajian Melayu \\ Universiti Malaya
}

\begin{abstract}
Abstrak
Emosi ialah tindak balas refleks yang dikaitkan dengan sistem saraf otak manusia. Emosi merupakan mekanisme untuk luahan komunikasi dan perasaan seseorang individu. Novel Penyeberang Sempadan (2012) karya Anuar Ridhwan dan novel Kafka On The Shore (2005) karya Haruki Murakami merupakan teks kajian yang mengandungi unsur psikologi yang dapat menjawab hipotesis dan persoalan terhadap emosi lelaki secara bandingan. Kajian ini berlandaskan bentuk-bentuk emosi yang disenaraikan oleh Daniel Goleman dalam Teori Kecerdasan Emosi (1995) iaitu emosi marah (anger), sedih (sadness), ketakutan (fear), keseronokan (enjoyment), kasih sayang/cinta (love), kejutan (surprise), kejijikan/ kebencian (disgust/hate) dan malu (shame). Bentuk-bentuk emosi dominan yang ditampilkan oleh watak lelaki protagonis dikesan melalui bait-bait ayat yang dikarang pengarang. Bentuk emosi yang dikesan kemudiannya dibandingkan untuk melihat persamaan bentuk emosi dominan yang sering dialami watak protagonis lelaki. Kajian dilakukan melalui pemerhatian terhadap perlakuan watak ketika berdepan dengan konflik dan masalah seterusnya memperlihatkan bentuk-bentuk emosi dominan watak lelaki dalam kedua-dua buah novel ini. Dapatan kajian
\end{abstract}


menunjukkan bentuk-bentuk emosi dominan dalam kedua-dua buah novel kajian ini menunjukkan persamaan yang seimbang apabila emosi sedih dikesan mendominasi hampir kedua-dua novel kajian dan terlihat pada watak protagonis lelaki yang dikaji. Watak protagonis lelaki dalam kedua-dua novel kajian mempamerkan emosi sedih secara produktif.

Kata kunci: Bentuk-Bentuk Emosi, Teori Kecerdasan Emosi, Daniel Goleman, Sedih, Emosi Dominan.

\section{Abstract}

Emotion is a reflexive reaction associated with the human nervous system, and a mechanism for communicating feelings. The novels "Penyeberang Sempadan" (2012) by Anuar Ridhwan, and "Kafka On The Shore" (2005) by Haruki Murakami, contain psychological elements which can answer and compare hypotheses regarding men's emotional problems. This study is based on the emotional forms categorized by Daniel Goleman in Emotional Intelligence Theory (1995) including anger, sadness, fear, pleasure, love, surprise, hate and shame. The dominant emotional forms are conveyed through the novels' male protagonists. The comparison of dominant emotional expressions between male protagonists is based on textual content found in both novels. The analyses are based in the conflicts and problems experienced by the male protagonists, and find dominant sad emotions in both novels.

Keywords: Emotional Forms, Emotional Intelligence Theory, Daniel Goleman, Sad, Dominant Emotion.

\section{Pendahuluan}

Dalam psikologi, emosi didefinisi sebagai tindak balas subjektif (perasaan) yang biasanya disertai oleh perubahan fisiologi. Emosi terjadi hasil daripada rangsangan, dorongan, pergolakan perasaan, fikiran, nafsu serta setiap keadaan mental yang meluap-luap. Emosi merupakan satu bentuk perasaan (feelings) atau pengalaman yang disedari yang kemudiannya diaktifkan oleh sebarang bentuk perangsang dalaman dan luaran sama ada secara fizikal ataupun spiritual. Emosi berubah mengikut persepsi, 
perasaan, naluri dan situasi yang mensimulasikan perasaan. Oleh itu, kajian ini dilakukan dengan menggunakan pendekatan psikologi yang bertujuan untuk mengesan dominasi bentuk-bentuk emosi pada watak lelaki protagonis yang terdapat dalam novel Penyeberang Sempadan (2012) karya Anwar Ridhwan dengan novel Kafka On The Shore (2005) karya Haruki Murakami secara bandingan.

\section{Definisi Emosi}

Emosi ialah satu keadaan motivasi yang ditandai oleh bangkitan fisiologi, tingkah laku ekspresif, dan pengalaman dan penilaian mental (Ma'rof Redzuan \& Haslinda Abdullah, 2002, p.170). Ahli-ahli psikologi memberikan fokus kepada aspek tingkah laku emosi yang berbeza mengikut kategori tingkah laku emosi seperti berikut:

i. Emosi diuja oleh peristiwa yang khusus;

ii. Emosi ialah tindak balas khusus yang begitu subjektif;

iii. Emosi muncul kesan daripada tindak balas terhadap matlamat atau motif yang penting kepada individu;

iv. Emosi ialah tindak balas terhadap peristiwa yang dinilai sebagai sebenar, dan kehebatan emosi ditentukan oleh sejauh mana kebenaran sesuatu peristiwa itu;

v. Emosi diuja oleh jangkaan terhadap perubahan individu dalam keadaan;

vi. Kenikmatan akan lenyap dengan kepuasan yang berterusan, kesakitan akan terus wujud dalam masa yang lebih panjang;

vii. Peristiwa emosi mengekalkan kuasanya untuk membangkitkan emosi secara kabur; dan

viii. Sesuatu emosi akan mengakibatkan emosi yang lain.

Emosi dilihat sebagai respons semula jadi manusia. Emosi semula jadi seperti marah, sedih, takut, seronok, sayang, terkejut, jijik dan malu merupakan respons neurobiologikal kimia. Terdapat beratus-ratus bentuk perasaan dan manusia cenderung untuk memberikan reaksi yang berbeza mengikut situasi yang terlibat pada masa kejadian tersebut berlaku. Emosi memainkan peranan sebagai pengaruh di bawah sedar (subconscious) 
kepada perhatian yang wujud sebelum perasaan ditunjukkan (Mok Soon Sang, 2010, p.18). Oleh itu, emosi dapat dikatakan sebagai tindak balas refleks yang dikaitkan dengan sistem saraf otak manusia. Emosi merupakan mekanisme untuk luahan komunikasi dan perasaan seseorang individu. dalam hal ini, Daniel Goleman (1995: p.209), menyenaraikan beberapa jenis bentuk emosi yang biasa dihadapi oleh seseorang individu seperti emosi marah (anger), sedih (sadness), ketakutan (fear), keseronokan (enjoyment), kasih sayang/cinta (love), kejutan (surprise), kejijikkan/ kebencian (disgust/hate) dan malu (shame).

Secara umumnya, emosi lahir daripada perasaan jiwa yang sangat kuat, yang boleh ditonjolkan melalui tindak balas tingkah laku seseorang secara psikologi, biologi dan melalui respons mental seseorang. Sehubungan itu, kajian ini dapat melihat bentuk-bentuk emosi yang mempengaruhi watak protagonis lelaki.

\section{Latar Belakang dan Permasalahan Kajian}

Kajian ini bermula daripada hipotesis bahawa tidak banyak kajian yang meletakkan watak dan perwatakan lelaki sebagai fokus kajian terutamanya daripada aspek psikologi. Sejak beberapa dekad ini, para pengkaji sastera cenderung untuk mengkaji wanita dan tidak banyak kajian yang memfokuskan watak dan perwatakan lelaki dalam kajian mereka secara perbandingan. Hal ini dibuktikan dengan kenyataan Nor Hashimah Jalaluddin \& Norsimah Mat Awal (2006: p.3) bahawa, "banyak kajian telah dilakukan mengenai wanita tetapi sebaliknya bagi lelaki". Justeru itu, kajian ini dilakukan dengan memaparkan dan menghuraikan bentukbentuk emosi lelaki daripada dua buah novel dari negara yang berbeza berdasarkan teori kecerdasan emosi yang digagaskan oleh Daniel Goleman.

\section{Metodologi Kajian}

Kajian ini menggunakan kaedah penyelidikan kepustakaan dan kaedah interpretasi (kualitatif) iaitu pemerhatian dan penelitian teks. Dalam kajian ini, Teori Kecerdasan Emosi Goleman akan diterapkan. Teori ini telah dipopularkan oleh Daniel Goleman pada tahun 1995. Dalam bukunya, Emotional Intelligence (1995: p.290), Daniel Goleman 
menyenaraikan bentuk-bentuk emosi seperti emosi marah, sedih, takut, keseronokan, terkejut, kasih sayang, benci dan malu. Bentuk-bentuk emosi ini dikesan kehadirannya melalui bait kata-kata, frasa, ayat, dialog, atau perenggan yang menunjukkan wujudnya bentuk emosi yang dialami oleh watak protagonis lelaki yang terdapat dalam novel Penyeberang Sempadan (2012) karya Anwar Ridhwan dengan novel Kafka On The Shore (2005) karya Haruki Murakami.

Watak lelaki yang dipilih untuk dianalisis terdiri daripada watak protagonis yang menonjolkan bentuk-bentuk emosi seperti yang disenaraikan oleh Daniel Goleman. Kewajaran pemilihan watak protagonis lelaki dalam kajian ini adalah selari dengan sikap manusia itu sendiri yang memiliki citra ragam dengan kepelbagaian pasang surut emosinya. Berdasarkan Rahman Shaari (2001: p.79), watak protagonis ialah watak utama suatu karya fiksyen. Protagonis tidak semestinya hero, yang penting dia menjadi watak dasar atau watak pusat. Perhatian pembaca tertumpu padanya. Menurut Shahnon Ahmad (1979: p.65) pula, watak penting dalam novel ialah watak yang mempunyai campuran sifat-sifat individual yang agak unik dengan sifat-sifat tipikal. Dalam kajian ini, bentuk emosi yang paling kuat atau dominan akan dibincangkan untuk melihat persamaan dan perbezaan bentuk emosi yang paling dominan yang ditampilkan dalam watak protagonis oleh Anwar Ridhwan dan Haruki Murakami dalam kedua-dua novel.

\section{Teori Kecerdasan Emosi Daniel Goleman}

Konsep kecerdasan emosi mempunyai sejarah yang panjang. Konsep dalam kecerdasan sosial mula diperkenalkan oleh Thorndike pada tahun 1920an sebelum diperkenalkan semula oleh Salovey dan Mayer pada tahun 1990. Sejak itu, elemen kecerdasan emosi telah mendapat tempat dalam kalangan ahli akademik. Pada tahun 1993, Gardner kemudiannya menerangkan konsep kecerdasan emosi melalui elemen kecerdasan intrapersonal dan interpersonal dalam kerangka "Pelbagai Kecerdasan" (Multiple Intelligence). Walau bagaimanapun, kenyataan Daniel Goleman dalam bukunya Emotional Intelligence (1996) bahawa "kecerdasan emosi lebih penting daripada kecerdasan kognitif tradisional (IQ)" menyebabkan konsep kecerdasan emosi menjadi satu konsep popular dalam kalangan 
masyarakat umum. Seterusnya Daniel Goleman, dalam bukunya Working with Emotional Intelligence (1998), telah mengemukakan model kecerdasan emosi dengan pembahagian dua kompenan kecerdasan emosi yang utama iaitu kecekapan peribadi (personel competence) dan kecekapan sosial (social competence). Kompenan kecerdasan emosi yang utama ini, kemudiannya dipecahkan kepada lima aspek yang saling berkait antara satu sama lain. Kompenan kecekapan peribadi meliputi tiga aspek utama iaitu mengenali emosi kendiri (self-awareness), mengurus emosi kendiri (self-regulation) dan motivasi kendiri (motivation). Manakala komponen kecekapan sosial mewakili dua aspek utama iaitu empati dan kemahiran sosial.

Manakala emosi, menurut Daniel Goleman (1995: p.289), merujuk perasaan dan pemikiran tersendiri yang menyebabkan berlakunya perubahan pada proses psikologi dan biologi seseorang yang mendorongnya untuk bertindak. Terdapat beratus-ratus jenis emosi yang wujud dalam diri setiap individu. Dalam hal ini, Daniel Goleman telah mengelaskan bentuk-bentuk emosi mengikut kategori seperti berikut:

i. Marah (Anger): berang, kejam, zalim, geram, murka, jengkel, sakit hati, meragam, permusuhan, dan sehingga pada satu tahap yang ekstrem, kemarahan yang tidak terkawal boleh bertukar menjadi kebencian dan keganasan.

ii. Sedih (Sadness): hiba, pilu, kedukaan, kehilangan keriangan, kelam, suram, melankolik, kasihan, kesepian, kekecewaan, putus asa, putus harapan dan apabila kesedihan tidak lagi terkawal kesedihan boleh membawa kepada tekanan perasaan atau depresi.

iii. Takut (Fear): kebimbangan, kerisauan, kecemasan, kekhuatiran, kebingungan, waswas, ragu-ragu, kegelisahan, keresahan, menggeletar ketakutan, gerun, gentar, sehingga pada yang tidak terkawal boleh bertukar menjadi fobia atau panik.

iv. Keseronokan (Enjoyment): keseronokan, riang, lega, puas hati, bahagia, menjerit keseronokan, menghiburkan, rasa dihargai, keghairahan yang menyenangkan, perasaan yang kuat, sangat keseronokan, memuaskan, kepuasan, rasa sangat keseronokan (euphoria), berperangai pelik atau ganjil (whimsy), keseronokan 
yang melampau boleh membawa kepada gangguan mental (mania).

v. Cinta/ Kasih sayang (Love): penerimaan, kemesraan, keramahan, kepercayaan, kebaikan, tertarik, kesetiaan, memuja, tergila-gila, ternganga/terlopong (agape).

vi. Kejutan (Surprise): terkejut, kehairanan, kekaguman, menakjubkan.

vii. Benci (Disgust): menghina, menafikan, menghindari, membenci, merendahkan.

viii. Malu (Shame): rasa bersalah, kesal, sesal, memalukan, mematahkan semangat, penyesalan, terhina.

(Daniel Goleman, Emotional Intelligience, 1995: p.289)

Bagi Daniel Goleman (1995: p.209), dalam setiap pengelompokan jenisjenis emosi ini, terdapat nukleus emosi asas sebagai teras yang setiap daripadanya membiakkan mutasi yang tidak terkira banyaknya yang disebut sebagai 'moods'. 'Moods' ini secara teknikalnya tidak disedari dan bertahan lebih lama dibandingkan dengan emosi. Selain itu, menurut Ramli Hassan (1990: p.9-10), efek atau emosi merujuk suasana perasaan yang menjadi pendorong utama dalam menentukan fikiran, sikap, tingkah laku seseorang individu, umpamanya perasaan riang, marah, bimbang, murung dan bersalah. Keadaan efek yang berpanjangan disebut moods atau rasa hati. Rasionalnya, teori ini dipilih berdasarkan penekanannya terhadap psikologi, emosi, tingkah laku dan tindakan watak meleraikan konflik yang dialami.

\section{Perbandingan Bentuk-bentuk Emosi Lelaki dalam Novel Penyeberang Sempadan (2012) dan Novel Kafka On The Shore (2005)}

Perbandingan bentuk-bentuk emosi dalam novel Penyeberang Sempadan (2012) dan novel Kafka On The Shore (2005) dapat dilihat dalam dua buah carta pai di bawah (A dan B) dan huraiannya dibuat selepas carta pai tersebut. 
Perbandingan Dominasi Bentuk Emosi Lelaki Dalam Novel Penyeberang Sempadan Dengan Kafka On The Shore

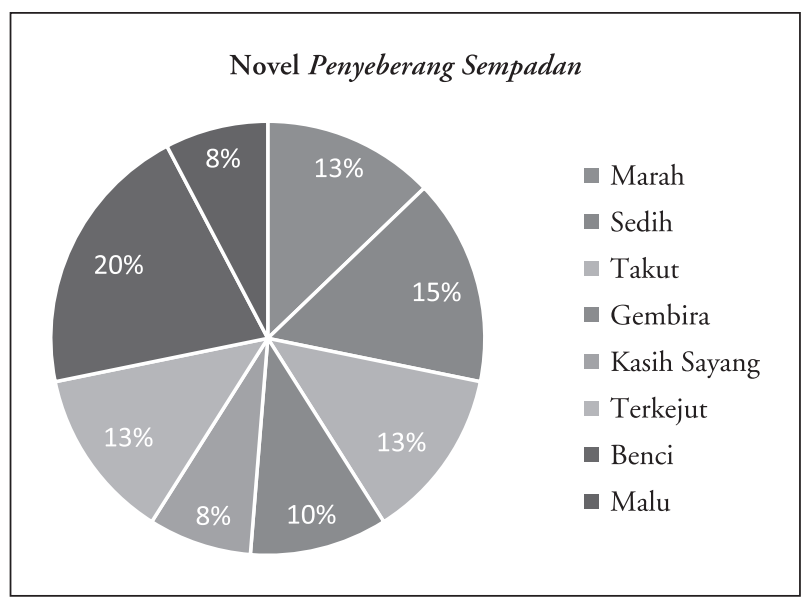

CARTA PAI A

Carta pai Pecahan Peratusan Bentuk-Bentuk Emosi Yang Terdapat Dalam Novel Penyeberang Sempadan (2012).

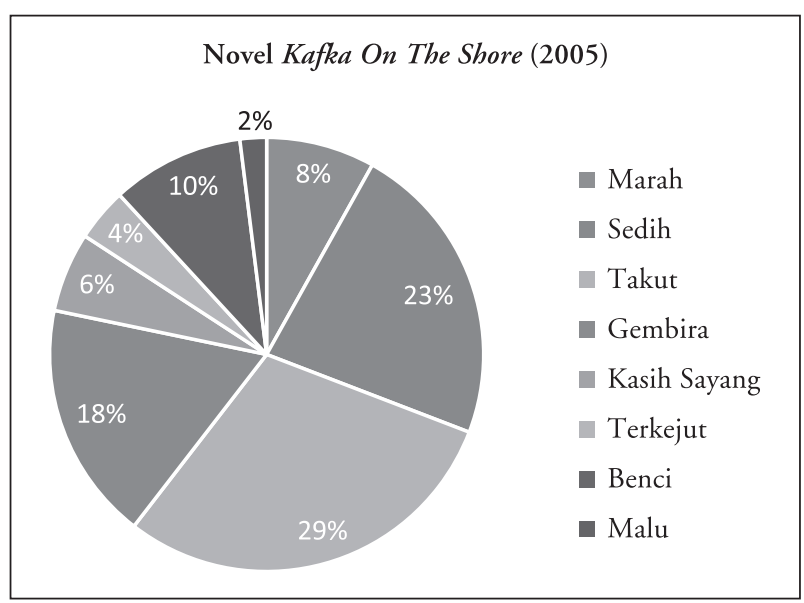

CARTA PAI B

Carta Pai Pecahan Peratusan Bentuk-Bentuk Emosi Yang Terdapat Dalam Novel Kafka On The Shore (2005). 
Carta pai A, iaitu pecahan peratusan bentuk-bentuk emosi yang terdapat dalam novel Penyeberang Sempadan (2012) di atas menunjukkan bahawa bentuk emosi yang paling banyak ditonjolkan oleh Anwar Ridhwan dalam novel Penyeberang Sempadan (2012) ialah bentuk emosi benci, iaitu $21 \%$, diikuti dengan emosi sedih $15 \%$, marah $13 \%$, takut $13 \%$, terkejut $13 \%$, keseronokan $10 \%$, kasih sayang $8 \%$ dan yang terakhir ialah emosi malu $8 \%$. Manakala carta pai B, pecahan peratusan bentukbentuk emosi yang terdapat dalam novel Kafka On The Shore pula menunjukkan bentuk emosi yang paling banyak ditonjolkan oleh Haruki Murakami ialah bentuk emosi takut, iaitu 29\%, diikuti dengan emosi sedih $23 \%$, keseronokan $18 \%$, benci $10 \%$, kasih sayang $8 \%$, terkejut $6 \%$, marah $4 \%$ dan yang terakhir ialah emosi malu sebanyak $2 \%$. Berdasarkan kedua-dua carta pai ini, didapati bahawa bentuk emosi yang dominan dalam novel Penyeberang Sempadan ialah emosi benci, sedih dan marah. Manakala bentuk emosi dominan lelaki dalam novel Kafka On The Shore ialah emosi takut, sedih dan keseronokan.

\section{Perbandingan Bentuk Emosi Dominan Lelaki Dalam Kedua-dua Novel Kajian}

Berdasarkan pemerhatian, didapati kedua-dua novel ini menunjukkan persamaan apabila emosi sedih merupakan antara emosi yang dominan yang menguasai watak-watak kajian. Dalam novel Penyeberang Sempadan (2012), emosi sedih muncul apabila watak Kuay kehilangan ayah yang sangat dikaguminya. Manakala, dalam novel Kafka On The Shore (2005) tulisan Haruki Murakami, emosi sedih muncul akibat daripada kehilangan ibu dan kakaknya serta penyisihan ayahnya terhadap dirinya. Emosi sedih ini terpamer melalui bait kata-kata, kalimat, ayat, frasa dan dialog yang disebutkan oleh watak Kafka Tamura dan Nakata dalam novel Kafka On The Shore (2005) dan watak Kuay dalam novel Penyeberang Sempadan (2012) seperti berikut:

"I can't remember the last time I laughed or even showed a hint of a smile to another person. Let alone myself.

(Kafka On The Shore, 2005: p.8) 
Am I really doing the right thing? The thought makes me feel helpless, isolated. I turn my back on the schoolkids and try not to look at them any more.

(Kafka On The Shore, 2005: p.36)

You're absolutely right. There's so much we have to remember, it is a pain.

(Kafka On The Shore, 2005: p.49)

I'm alone, inside the world of the story. My favourite feeling in the world.

(Kafka On The Shore, 2005: p.61)

And Nakata could well imagine how awful this pain was.

(Kafka On The Shore, 2005: p.155)

"...I do feel sad. He's my father, after all..."

(Kafka On The Shore, 2005: p.214)

Pada saat itulah aku mula berasa kehilangannya. Dalam sukmaku, ruang yang selama ini didiami ayah, tiba-tiba menjadi kosong sepi.

(Penyeberang Sempadan, 2012: p.33)

Kadang-kadang aku berasa, aku ini seperti melukut di tepi gantang saja. Aku dan namaku seolah-olah hanya digunakan untuk menunjukkan bahawa aku ini Melayu, dan dengan itu mewakili perjuangan orang-orang Melayu. Terus-terang aku berasa hati.

(Penyeberang Sempadan, 2012: p.124)

Selama beberapa hari selepas peristiwa yang agak meminggirkan aku itu, rasa kecewa merobek-robek sukmaku.

(Penyeberang Sempadan, 2012: p.125) 
Kalaulah tidak ada Yan dan Shafíaa di rumah limas itu, Kuay ingin menangis. Dia melihat rumah limas itu masih macam dulu, kecuali semakin tua dan buruk. Kuay jenguk bilik tidurnya dulu. Jenguk dapur. Tengok tingkap, dinding, jenang pintu dan daun pintu yang sama!

(Penyeberang Sempadan, 2012: p.125)

Ungkapan-ungkapan ini jelas memperlihatkan emosi sedih yang membelenggu kehidupan watak-watak protagonis lelaki dalam keduadua buah novel kajian. Emosi sedih yang ditampilkan ini bertepatan dengan terjemahan kesedihan yang disebutkan oleh Ponnusamy Subramaniam \& Shazli Ezzat Ghazali (2010: p.10), kesedihan atau kehibaan merupakan tindak balas atau reaksi semula jadi terhadap kehilangan yang signifikan ataupun yang diduga. Selain itu, menurut Lamia, Mary C (2013: p.83) Emotions regarding loss can be triggered throughout one's life and continued to cause sadness, althought he feelings may not interfere with everyday functioning. Akibat kehilangan, emosi sedih boleh mempengaruhi kehidupan seseorang, walaupun secara zahirnya emosi tersebut tidak mengganggu rutin harian seseorang.

Hal inilah yang berlaku pada watak Kuay dalam novel Penyeberang Sempadan (2012) dan Kafka Tamura dalam novel Kafka On The Shore (2005). Emosi sedih akibat kehilangan orang yang disayangi tidak mengganggu rutin harian mereka, tetapi telah mengakibatkan kehidupan mereka berubah. Dalam novel Penyeberang Sempadan (2012), Kuay sangat terpukul dan terkejut dengan peristiwa kematian ayahnya sehingga memberikan kesan terhadap perkembangan kehidupan remajanya. Kebenciannya terhadap Inggeris menebal dan dia nekad untuk membalas dendam. Kuay mula mencari-cari ideologi yang dapat membantunya menuntut keadilan. Menurut Nurhidayati \& Lisya Chairani (2014: p.42) "Kematian merupakan fakta biologi namun kematian juga mempunyai dimensi sosial dan psikologi...menghadapi kematian orang tua di usia dini merupakan ujian yang berat bagi setiap remaja."

Kesedihan bagi Kafka Tamura dalam novel Kafka On The Shore (2005) timbul apabila dia telah ditinggalkan oleh ibu dan kakaknya ketika dia berusia empat tahun lagi. Sejak itu, dia dibesarkan oleh bapanya tanpa kasih sayang sebenar daripada seorang bapa. Dia sering diabaikan 
oleh bapanya sendiri lantaran dendam dan benci bapanya terhadap ibunya. Keadaan tersebut menyebabkan Kafka Tamura berasa kesunyian dan keseorangan lantas membangkitkan emosi sedih dalam diri. Hal ini selari dengan yang kenyataan Daniel Goleman (2002: p.209) iaitu, emosi sedih terjadi disebabkan oleh wujudnya rangsangan sama ada dari luar ataupun dari dalam diri individu itu sendiri.

Kehibaan atau kesedihan dimanifestasi sebagai satu perkembangan emosi, sosial, kerohanian, fizikal, kognitif dan perubahan tingkah laku sepanjang hayat, apabila seseorang individu cuba mengatur semula dan menyelesaikan atau menyesuaikan diri terhadap kehilangan dengan kemampuan yang tersendiri (Ponnusamy Subramaniam \& Shazli Ezzat Ghazali, 2010: p.10). Keadaan ini turut terlihat pada watak Nakata dalam novel Kafka On The Shore (2005).

They tell me before the accident Nakata always got good marks. But then I collapsed and when I woke up I was not so bright. My mother died a long time ago, but she used to cry about this a lot. Because I became stupid. My father never cried, but he always angry."

(Kafka On The Shore, 2005: p.53)

Petikan ini jelas menunjukkan perubahan yang berlaku pada diri Nakata, yang menyebabkan emosi sedih muncul. Daripada seorang yang cerdik dan menjadi tidak cerdik, kesedihan ibunya terhadap nasib yang menimpa dirinya, kematian ibunya dan kekecewaan bapanya serta perubahan sikap bapanya yang suka marah, menimbulkan perasaan sedih dalam diri Nakata. Berdasarkan peristiwa-peristiwa yang membelenggu watak-watak lelaki ini, dapat dilihat bahawa mereka memahami emosi sedih yang membelenggu diri mereka selari dengan penjelasan Daniel Goleman seperti berikut:

"Another emphasis is managing emotions: realizing what is behind a feeling (for example, the hurt that trigger anger), and learning ways to handle anxities, anger, and sadness. Still another emphasis on taking responsibility for decisions and actions, and following through on commitments."

(Emotional Intelligence, 1995: p.268) 
Daripada pemaparan peristiwa-peristiwa yang membangkitkan emosi sedih seperti di atas, ternyata watak-watak protagonis kajian memahami perasaan sedih yang membelenggu diri mereka. Hal ini selari dengan pandangan Daniel Goleman, bahawa penekanan yang dititikberatkan dalam mengendalikan emosi adalah dengan memahami perasaan yang sedang dialami seperti kesakitan yang menimbulkan emosi marah dan proses pembelajaran untuk mengendalikan kesakitan, kemarahan dan kesedihan. Penekanan lain termasuklah bertanggungjawab dan komited ketika bertindak dan membuat keputusan.

Selain emosi sedih, emosi benci dalam novel Penyeberang Sempadan (2012) juga didapati dominan. Emosi benci menurut Daniel Goleman (1995: p.209) ialah menghina, menafikan, menghindari, membenci dan merendahkan. Emosi benci merupakan sebuah emosi yang sangat kuat untuk melambangkan perasaan tidak suka yang boleh mendorong perasaan dendam. Emosi benci juga boleh mencetuskan keinginan seseorang untuk menghindari, menghancurkan atau menghilangkan sesuatu yang tidak disukai. Dalam novel Penyeberang Sempadan (2012), emosi benci didapati banyak ditonjolkan melalui watak Kuay. Seorang remaja lelaki berusia belasan tahun yang terlalu benci akan kezaliman penjajah hingga menyebabkan dia membuat keputusan besar untuk meninggalkan kampung halamannya demi mencari sebuah ideologi yang boleh memberikan kemerdekaan, kebebasan, keadilan dan kebenaran sebenar kepada penduduk Kampung Kuala Tuntung khususnya dan kepada Malaya secara amnya. Kebenciannya terhadap penjajah meninggalkan kesan yang besar pada kehidupannya yang jelas terlihat seperti sebuah dendam kesumat. Hal ini boleh diperhatikan seperti petikan berikut;

"Faktor pertama yang mendorongnya jadi orang perjuangan bukanlah kerana cita-cita politik nasional, tapi dendam peribadi terhadap golongan tertentu. Semacam personal revenge"

(Penyeberang Sempadan, 2012: p.94)

Kenyataan di atas menunjukkan bahawa kebencian yang mendalam terhadap penjajah menimbulkan perasaan dendam hingga menyebabkan Kuay bangkit untuk membalas dendam dan menuntut bela ke atas kematian ayahnya. Kematian ayah yang sangat dikagumi dan dikasihi 
memberikan kesan yang cukup besar dalam hidup Kuay. Emosi benci dan dendam bersatu dalam dirinya yang terlihat melalui bait-bait petikan berikut;

"Kerana suatu peristiwa lampau di tanah kami itulah, secara beransur-ansur, aku membenci sesuatu dan mengimpikan sesuatu."

(Penyeberang Sempadan, 2012: p.22)

"Inggeris jahanam itu! Inggeris yang datang menjajah tanah airku untuk mengembangkan kuasa dan merompak kekayaan Malaya."

(Penyeberang Sempadan, 2012: p.29)

"Raksasa itu terus membesar dalam sukmaku. Badang telah mati. Ayahku telah mati. Atas kematian itu, di atas tanah perkuburan ayah yang masih merah lembab, aku tiba-tiba berasa ingin sekali membunuh raksasa itu."

(Penyeberang Sempadan, 2012: p.34)

Berdasarkan petikan-petikan di atas, jelas kelihatan betapa bencinya watak Kuay terhadap Inggeris, penjajah yang menjajah Malaya, sekali gus, menunjukkan emosi benci mendominasi sebahagian besar bentuk emosi dalam novel Penyeberang Sempadan (2012). Kebencian terhadap kezaliman Inggeris menyebabkan watak Kuay memasang tekad untuk menghapuskan Inggeris. Dia mula menyertai gerakan haluan kiri yang dirasakan dapat membebaskan Malaya daripada cengkaman Inggeris pada ketika itu.

Hal ini berbeza dengan novel Kafka On The Shore (2005) kerana emosi benci tidak terlalu dominan sebaliknya emosi takut lebih dominan novel ini. Hal ini ketara melalui dua watak protagonis iaitu Kafka Tamura, seorang remaja lelaki berusia 15 tahun dan Nakata seorang lelaki tua dungu yang buta huruf. Kafka Tamura sering dibayangi perasaan resah dan takut dengan sumpahan yang merupakan kata-kata sumpahan bapanya sejak dia kecil. 
"When Kafka is a young boy, his father tells him: Someday you will murder your father and be with your mother."

(Kafka On The Shore, 2005: p.202)

Kata-kata sumpahan daripada bapanya ini sering menghantui watak Kafka Tamura. Ketakutan terhadap perkara yang disebutkan oleh bapanya iaitu suatu hari nanti dia akan membunuh bapanya dan dia akan bersama dengan ibunya telah mendorongnya memilih untuk melarikan diri dari rumah kerana dia tidak mahu perkara tersebut menjadi kenyataan. Hal ini yang dikatakan bahawa, perasaan takut boleh mendorong seseorang individu untuk bertindak di luar kebiasaan mereka sebagaimana yang disebutkan oleh Asmawati Desa \& Juriah Daud (2006: p.56) iaitu perasaan takut akan memotivasikan individu untuk lari atau mungkin juga melawan. Reaksi kecemasan ini selalunya dikenali sebagai tindak balas lawan atau lari. Reaksi kecemasan ini ditonjolkan oleh Haruki Murakami melalui peristiwa Kafka Tamura melarikan diri daripada bapanya ketika hari ulang tahunnya yang kelima belas untuk mengubah takdir yang disebutkan bapanya. Selain itu, bagi mengelakkan dirinya dijejaki, dia telah mengubah namanya kepada Kafka Tamura. Reaksireaksi ini merupakan bentuk tindak balas lawan yang ditonjolkan pengarang melalui watak Kafka Tamura.

Emosi takut semakin membelenggu watak Kafka Tamura apabila dia terpaksa berdepan dengan pelbagai kejadian aneh. Antara kejadian aneh yang menimpa dirinya termasuklah dia telah mendapati dirinya pengsan di dalam semak dalam keadaan berlumuran darah tanpa sebarang kecederaan. Peristiwa itu malah gagal diingatinya. Selain itu, bapanya juga telah didapati mati dibunuh dan pihak berkuasa sedang mencari penjenayah yang melakukan perkara tersebut. Kejadian tersebut telah menyebabkan ketakutan Kafka Tamura semakin bertambah kerana ilusi dan fantasinya sering mengatakan bahawa dia telah membunuh bapanya. Dia juga diburu oleh pihak polis kerana disyaki sebagai suspek utama bagi kes pembunuhan bapanya. Keadaan ini menyebabkan Kafka Tamura terus menjadi seorang pelarian hingga menyebabkan emosi takutnya semakin memuncak. 
Menurut Rachman (1974: p.52), emosi takut terdiri daripada empat kompenan, iaitu pengalaman subjektif tentang takut, perubahan fisiologi yang berlaku, kesan takut yang ditunjukkan, dan percubaan untuk menghapuskan sumber ketakutan. Dengan perkataan lain, apabila individu mengalami situasi yang menakutkan, badannya akan bertindak balas terhadap perasaan takut tersebut. Perasaan takut itu selalunya dapat diperhatikan, dan akhir sekali individu itu selalunya akan cuba menguruskan situasi tersebut.

Selain emosi sedih, benci dan takut, emosi marah pula merupakan emosi ketiga tertinggi yang dipamerkan oleh Anwar Ridhwan menerusi novel Penyeberang Sempadan (2012). Giovanni Frazzetto berpandangan bahawa (2013: p.13), Anger exemplifies the irrepressible vigour of the emotions. It puts our judgements to the test, forcing us to consider how to behave in fruststrating circumstances, respond adequately to offence, and decide on the best action. Anger is entangledf with choice. Feeling anger raises questions of values and option, and thus of ethics, morality and conduct. Kenyataan Giovanni Frazzetto ini jelas menunjukkan bahawa emosi marah merupakan emosi yang dapat menjana perasaan yang sihat dalam diri individu. Emosi marah mendorong seseorang itu untuk membuat penilaian terhadap setiap masalah yang berlaku dengan memaksa individu untuk bertindak sebaik mungkin semasa berdepan dengan situasi yang mengecewakan, bertindak balas sewajarnya untuk mempertahankan diri dan membuat keputusan terbaik. Selain itu, emosi marah turut bersangkutan dengan pilihan. Perasaan marah menimbulkan persoalan mengenai nilai, pilihan, etika, moral dan tingkah laku. Jelas di sini, emosi marah adalah antara emosi dominan yang diperlihatkan oleh Anwar Ridhwan dalam novel Penyeberang Sempadan (2012) selain emosi sedih dan benci.

Manakala dalam novel Kafka On The Shore (2005), emosi keseronokan ialah emosi ketiga terbanyak yang ditampilkan oleh Haruki Murakami iaitu sebanyak 18\%. Walaupun emosi takut dan sedih dominan dalam novel ini, namun watak-watak lelaki dalam novel ini turut menikmati emosi keseronokan. Emosi keseronokan dikesan berdasarkan kekerapan watak Kafka Tamura dan Nakata meluahkan emosi seronok mereka. Rasa gembira watak Kafka Tamura terserlah melalui keseronokannya yang dapat menghabiskan masa di perpustakaan untuk membaca buku. Manakala emosi keseronokan watak Nakata dikesan 
melalui berbangga terhadap keupayaan dirinya sebelum dia jatuh sakit. Menurut Ekman (2003: p.118), "There are many emotions that have to do with happiness, including elation, gladness, relief, joy, bliss and amusement. Althought these happy emotions all differ in terms of how they are experienced, they are represented by a similar facial expression..." Berdasarkan kenyataan Ekman ini, ternyata terdapat banyak emosi yang mempunyai kaitan dengan keseronokan dan antaranya termasuklah keseronokan, sukacita, kelegaan, kebahagiaan dan hiburan. Sungguhpun setiap emosi keseronokan berbeza mengikut pengalaman yang dilalui seseorang individu, namun begitu, emosi tersebut boleh dikesan melalui ekspresi wajah yang sama. Hal inilah yang terpamer pada watak Kafka Tamura. Walaupun secara zahirnya dia tidak memiliki seorang kawan pun semasa di sekolah, namun dia bahagia dan seronok dengan situasi tersebut. Malah dia bersyukur kerana mereka tidak mengganggunya. Selain itu, Kafka Tamura juga menikmati emosi keseronokan saat dia menghabiskan masanya untuk membaca buku.

"You like to read good books, to work things out on your own. You look like you're in good shape physically, and you're an independent kind of guy. You like to lead a well-regulated life and have a lot of will-power. I mean, even the will-power to make your stomach smaller, right? I'll talk with Miss Saeki about you beccoming my assistant and staying in the empty room here at the library".

(Kafka On The Shore, 2005: p.115)

Petikan di atas jelas menunjukkan minat Kafka Tamura terhadap buku dan bacaan yang baik turut disedari oleh rakannya, Oshima. Membaca buku merupakan terapi yang terbaik untuk dia melupakan segala permasalahan yang berlaku. Buat kali pertamanya juga, Kafka Tamura berasa seronok apabila dia dapat melarikan diri dari rumah. Pada saat dan ketika itu, dia dapat merasakan dirinya telah cukup bebas untuk melakukan apa-apa sahaja yang diingini selama ini terutamanya menghabiskan masa sepanjang hari di perpustakaan untuk membaca buku dan dibuktikan melalui petikan ini:

"I decide to kill time till the evening at a library. Ever since I was litte I've loved to spend time in the reading rooms of libraries..."

(Kafka On The Shore, 2005: p.34) 
Berdasarkan peristiwa-peristiwa yang dilalui watak-watak kajian, sebahagian besarnya memaparkan bahawa mereka sentiasa bergelut dengan pelbagai bentuk emosi dan konflik kejiwaan. Menurut Abdullah Hassan \& Ainon Mohd (1997: p.106), terdapat dua jenis konflik iaitu konflik isi dan konflik perhubungan. Konflik isi ialah konflik yang berpusat pada benda, perkara, peristiwa atau individu lain yang menjadi punca konflik tersebut. Manakala konflik perhubungan ialah konflik yang melibatkan diri individu itu sendiri. Konflik perhubungan boleh terjadi apabila wujudnya percanggahan pendapat, tiada persefahaman dalam membuat keputusan atau tidak berbincang sebelum membuat sesuatu perkara sehingga mencetuskan pelbagai masalah. Secara amnya, keduadua bentuk konflik ini ada di dalam kedua-dua novel kajian.

Secara keseluruhannya, emosi sedih, benci dan marah merupakan emosi yang dominan dalam novel Penyeberang Sempadan (2012) dan emosi sedih, takut dan keseronokan merupakan emosi dominan yang terdapat dalam novel Kafka On The Shore (2005) manakala emosi malu merupakan bentuk emosi yang paling sedikit ditampilkan oleh Anwar Ridhwan dan Haruki Murakami di dalam kedua-dua novel ini. Hal ini sejajar dengan kenyataan yang disebutkan oleh Sahlan Mohd Saman (1986: p.52), iaitu sebuah hasil sastera itu tidak boleh lari daripada soal emosi; emosi penulis itu sendiri atau watak-watak yang lahir sebagai pengganti dirinya. Watakwatak dalam setiap karya sastera hidup dan bergerak. Tambah beliau lagi, seorang pengarang amat perlu menyesuaikan tindak-tanduk perwatakan yang dicernakan pada sebuah karya sastera. Soal-soal konsistensi perlakuan watak, penerimaan pembaca dan pengkritik, logik atau tidak logik pada penerimaan akal yang waras ialah faktor-faktor utama dalam sesuatu karya sastera, terutamanya yang berbentuk prosa.

\section{Rumusan}

Berdasarkan pemerhatian yang dilakukan terhadap novel Penyeberang Sempadan (2012) karya Anwar Ridhwan dan novel Kafka On The Shore (2005) karya Haruki Murakami, bentuk-bentuk emosi watak dalam kedua-dua buah novel kajian ini menunjukkan persamaan yang seimbang apabila emosi sedih dikesan mendominasi hampir kedua-dua novel kajian. Emosi sedih terlihat pada watak protagonis lelaki yang dipilih. 
Hasil pemerhatian menunjukkan watak protagonis dalam keduadua novel kajian mempamerkan emosi sedih secara produktif. Emosi sedih yang diekspresikan oleh watak-watak lelaki kajian menonjolkan sensitiviti, kerendahan dan kelembutan hati seorang lelaki. Emosi sedih bukanlah satu bentuk emosi yang bersifat negatif tetapi emosi sedih merupakan emosi normal yang dapat diterima oleh setiap insan bergelar manusia sebagaimana bentuk-bentuk emosi yang lain bergantung pada kebijaksanaan watak menangani emosi tersebut.

Seterusnya, perbandingan turut menampakkan beberapa persamaan faktor yang membentuk emosi sedih watak lelaki dalam kedua-dua novel kajian tersebut, antaranya kehilangan sesuatu yang disayangi, keadaan keluarga yang kucar kacir serta bermasalah, ketandusan kasih sayang, putus asa dengan hidup dan konflik jiwa yang dialami. Hal ini ditemui melalui analisis watak-watak lelaki berdasarkan peristiwa-peristiwa yang dialami dalam kehidupan seharian mereka. Selain itu, perbandingan menunjukkan persamaan pemaparan emosi malu yang ternyata paling sedikit ditampilkan oleh Anwar Ridhwan dan Haruki Murakami dalam novel-novel kajian.

Sebagai penutup, walaupun pemaparan bentuk-bentuk emosi telah mengikut klasifikasi bentuk emosi yang disenaraikan oleh Daniel Goleman, klasifikasi senarai bentuk emosi tersebut didapati masih boleh dipertikaikan ketepatannya terutamanya untuk menilai emosi yang membelenggu sesuatu watak. Malah Daniel Goleman dalam bukunya Emotional Intelligence (1995: p.290) turut menyarankan supaya kajian lanjut dilakukan untuk mengklasifikasikan bentuk-bentuk emosi yang membelenggu manusia dengan lebih tepat.

\section{Bibliografi}

Abdullah Hassan \& Ainon Mohd. (1997). Menyelesaikan konflik. Kuala Lumpur: Utusan Publication \& Disttributors Sdn Bhd.

Anwar Ridhwan. (2001). Penyeberang sempadan. Kuala Lumpur: Dewan Bahasa dan Pustaka. 
Asmawati Desa \& Juriah Daud. (2006). Remaja masih takut?. In Rohany Nasir \& Fatimah Omar (Eds.), Kesejahteraan manusia, perspektif (pp. 51-62). Selangor: Penerbit UKM.

Ekman, P. (2003). Emotions revealed: Recognizing faces and feelings to improve communication and emotional life. New York, NY: Holt.

Giovanni Frazzetto. (2013). Joy, guilt, anger, love. New York. Penguin Books.

Goleman, D. (1995). Emotional intelligence. New York: Bantam Books.

Goleman, D. (1998). Working with emotional intelligence. Great Britain: Blommsbury Publishing Plc.

Lamia, Mary C. (2013) Emotions! making sense of your feelings. Washington, DC: Magination Press.

Ma’rof Redzuan \& Haslinda Abdullah. (2002). Psikologi. Selangor: Mc Graw Hill.

Murakami, Haruki, (2005). Kafka on the shore. Gabriel, P (trans). London: Harvill.

Mok Soon Sang. (2010). Kompetensi kecerdasan emosi. Puchong Selangor: Penerbitan Multimedia Sdn Bhd.

Nor Hashimah Jalaluddin \& Norsimah Mat Awal. (2006 ). Citra lelaki dulu dan kini dalam prosa Melayu: analisis Teori Relevans. Jurnal eBangi, Vol. 1(Num. 1), 3.

Nurhidayati \& Lisya Chairani. (2014). Makna kematian orangtua bagi remaja (studi fenomenologi pada remaja pasca kematian orangtua). Jurnal Psikologi, Volume 10 Nomor 1, Juni 2014.

Ponnusamy Subramaniam \& Shazli Ezzat Ghazali. (2010). Psikologi kehibaan. Selangor: Penerbit UKM.

Rachman, S. (1974). The meaning of fear. Baltimore: Penguine Books.

Rahman Shaari, 2001. Bimbingan Istilah Sastera. Kuala Lumpur. Utusan Publications \& Distributors Sdn. Bhd. 
Ramli Hassan. (1990). Pengantar psikiatri. Kuala Lumpur Dewan Bahasa dan Pustaka.

Richard Gillett. (2005). Mengatasi tekanan. Petaling Jaya: Golden Books Centre Sdn. Bhd.

Robert Plutchik. (1953). The emotions facts, theories and new model. New York: Random House.

Rohany Nasir \& Farimah Omar. (2006). Kesejahteraan manusia: perspektif psikologi. Selangor: Penerbit Universiti Kebangsaan Malaysia.

Rosinah Edinin. (2011). Penyelidikan tindakan, kaedah dan penulisan. Kuala Lumpur: Freemind Horizon Sdn. Bhd.

Sahlan Mohd Saman. (1986). Sastera bandingan, teori, konsep dan amalan. Petaling Jaya: Penerbit Fajar Bakti Sdn. Bhd.

Sahlan Mohd Saman. (1994). Pengantar kesusasteraan bandingan (S. Jaafar Husin. Ed). Kuala Lumpur: Dewan Bahasa dan Pustaka.

Shahnon Ahmad. 1979. Gubahan Novel. Kuala Lumpur: Dewan Bahasa dan Pustaka. 